\title{
The Influence of Supervision School Principals and Teachers Work Motivation to Work Discipline in Public Primary Schools
}

\author{
Eka Herawati ${ }^{* *}$, Edi Harapan ${ }^{2}$, Tahrun ${ }^{2}$ \\ ${ }^{1}$ SD Negeri Sidomukti, South Sumatra, Indonesia \\ ${ }^{2}$ Universitas PGRI Palembang, Indonesia \\ ${ }^{*}$ Corresponding author. Email: ekaherawatispd@gmail.com
}

\begin{abstract}
This research aims to review the influence of supervision school principals and teachers work motivation against disciplinary work. The study was conducted in public primary schools. This research is kind of quantitative research with a research design used design expost-facto research study. Included in this research is the total public-school teachers consisting of two teachers, the survey data collection techniques using. Data analysis techniques using a technique descriptive analysis quantitative, and of multiple regression. The results of this research stated that: (1) there are significant influence supervision of the head of the schools to work problems of public school; (2) there are significant influence between the motivation of teachers have to work problems of public school; and (3) there are significant influence between supervision of the head.
\end{abstract}

Keywords: Supervision, Job Motivation, Work Problems

\section{INTRODUCTION}

To the improving quality education is very affected by the teachers in the duties and functions at school. Teacher attendance in learning very important, that is because teachers are of teachers that periodically direct interaction with students, for that required intensive guidance and services in line with the students [1], [2], [3]. Discipline required a master in learning school work [4], [5], [6].

Said discipline derived from student which means a follower or students from the leader who have. Term discipline means systematic instruction given are as the learner to train them as students and handicrafts [7], [8], in trade sector or for a board an ethical or a certain rule code.

Discipline as much as someone to involve demands good governance so consciously with to obey the rules. Discipline closely linked the mental and moral character inherent in a person. Awareness contains a restraint, and by the presence of self-control on individual mental attitude will be implanted high moral.

\section{METHODS}

\subsection{The Types of Research}

This study uses research methodology quantitative research focused on the objective to study examined quantitatively. Data collection is done quantitative research. This method uses the partial correlation research, a partial correlation in which used for analysis or the testing of hypotheses, research design it uses design studies on expost based on the methodology.

\subsection{The Subject and of Research Data}

Subject of study is all teachers in public primary schools as a rayon Plakat Tinggi district consisting of the 101 teachers. Technique use questionary survey data collection, documentation and observation.

\section{RESULTS AND DISCUSSION}

From the data analysis that its motivation supervision school principals and teachers ' work together to influential discipline primary. Based on the simple regression, obtained the $\mathrm{t}$ count of 5,570 $\mathrm{t}$ of the table and the price of 1,652 And the price t count more than $t$ 
table hence ho2, rejected and there were significant influence of the incentives to work problems public school teachers working, obtained $\mathrm{f}$ count with the significance of $151,716>0,000$; value probability 0,05 while $\mathrm{f}$ table in accordance with standard significance 0,$05 ; 3,04$ of also count $<\mathrm{f}$ table $(151,716<3,04)$, turning in it means there were significant influence in together as academic work and motivation of teachers to work problems as a public school in plaque. high area. Based on the value of $r$ square 0,614 thus determinacy coefficient of 61,4 percent so that it can be concluded that big the influence of supervision school principals and teachers working motivation to work problems as public school district was a placard on high Together of $61,4 \%$ and the rest $38,6 \%$ in others effect by a factor in research study.

The process of education happens effectively and efficiently when teachers have adequate competence. But unless we understand back about the contained in any kind of competence, as experts often disclosed by education to being a teacher competent not easy [9], [10], [11]. But influenced by competence, a teacher was also influenced by the leadership of the school principal. The role of school principals in improving the competence of teachers and teacher will increase the performance of indispensable. Including teachers Routinely in training program, empower teachers, encourage and directions is the responsibility of the school principal in developing competence of teachers. Including the procurement that led to a better teacher performance became the responsibility of the school.

To create and improve competence of teachers needed business seriously either from teachers itself, the school principal, supervisory [12], [13], [14] and government from research shows that there has been a positive influence from the influence of the principal supervision, and the better application of supervision school principals and also will increase the performance of teachers. This is in line with the research regression models of the accuracy of the testing obtained from the $f$. Based on the results of the analysis, obtained the $f$ count $=68,337$ and value $\mathrm{f}$ table $=2,674 \mathrm{f}$ count ; table with probabilities 0,000 smaller than 0,05 . This indicates that performance variables teachers can be explained by the variation's motivation, variable work school climate, and satisfaction significant on real work standard 5\%. Results also because obviously if teachers motivation, having work will to work and responsibilities the good. In the end, discipline working along with that if teachers work and responsibilities the good work according to its capacity means discipline was performance best that is in him. Research findings teachers' work shows that motivation in discipline influential significantly to work [15], [16].
This means better and teachers' work high motivation will followed by improving discipline work and if work fell motivation teachers to exert an influence upon discipline work suggests that someone will work in professional when the person having the ability and motivation (motivation). Is someone will work in professional ability work when someone has high and motivation to do good. And, no will work in professional when only meet one the above conditions. So, no matter how high a person capacity he would not have employed professionally if not having high motivation work [17], [18]. In other words, the motivation is a component most important and influential in the performance of someone. Discipline work in an activity is the learning teaching materials to be achieved by each teacher at school, based on with the curriculum.

The amount of curriculum so summarized in teaching are often not commensurate a time available on the day effective on the other hand, all teachers are required to be able to meet the target. For it, the need of the work carried out in school problems [19], [20]. Considering that the duty and role of a teacher who is very large and it is the pivotal to the education sector, so a teacher should be able to put the right to be professional workers, in accordance with the demand of the growing [21], [22]. As an educator, teachers to teach and planting and attitude to their students, to carry out the mission is a teacher must have a variety of competence and personality who dances.

\section{CONCLUSION}

Based on the analysis of the data and the testing of hypotheses will be as follows: (1) there are significant influence between supervision of public school disciplinary academic work; (2) there are significant influence of the incentives work disciplinary work they think of public primary schools; and (3) there are significant influence in together as academic work and motivation of teachers to work problems as public school.

\section{REFERENCES}

[1] Abdullah, A. Z., Hamzah, A., \& Mulyono, M. H (2013). Faktor yang Berpengaruh terhadap Kinerja Perawat di Rumah Sakit Tingkat III 16.06. 01 Ambon. Jurnal Administrasi dan Kebijakan Kesehatan Indonesia, 2(01), 8270

[2] Amanda, M. O., Salam, R., \& Saggaf, S. (2017, February). Pengaruh Supervisi Kepala Sekolah Terhadap Kinerja Guru Di SMK Negeri 1 Bungoro Kabupaten Pangkep. In Prosiding Seminar Nasional Himpunan Sarjana Ilmu-ilmu Sosial (Vol. 2, pp. 149-154).

[3] Anoraga. (2011). Psikologi Manajemen. Rineka Cipta, Bandung. 
[4] Anggraeni, I., Komariah, A., \& Kurniatun, T. C. (2016). Kinerja Manajerial Kepala Sekolah, Displin kerja dan Mutu Sekolah Dasar. Jurnal Administrasi Pendidikan, 23(2).

[5] Arikunto, S. (2012). Dasar-dasar Supervisi, Jakarta. Rineka Cipta.

[6] Arikunto, S. (2010). Prosedur Penelitian Suatu Pendekatan Praktek. Jakarta: Rineka Cipta

[7] Auliya, U. U., Thomas, P., \& Latifah, L. (2012). Pengaruh Supervisi Kepala Sekolah dan Motivasi Kerja Guru Terhadap Kinerja Guru. Economic Education Analysis Journal, 1(2), 8-13.

[8] Burhan, B., Asmara, U. H., \& Aswandi, A. (2015). Pengaruh Supervisi Akademik dan Motivasi Kerja Kepala Sekolah Terhadap Disiplin Kerja Guru SD. Jurnal Pendidikan dan Pembelajaran Khatulistiwa, 6(12).

[9] Chukwuma, E.M., \& Obiefuna, O. (2014). Effect of Motivation on Employee Productivity: A Study of Manufacturing Companies in Nnewi. Journal of Managerial Studies and Research, 2(7).

[10] Cici, S., \& Nurdin. (2011). Manajemen Pendidikan, Supervisi Pendidikan. Cet. IV. Bandung: Alfabeta.

[11] Darmawati, D., Munjin, R. A., \& Seran, G. G. (2017). Pengaruh Supervisi Kepala Sekolah Terhadap Kinerja Guru Di SMP Negeri 1 Parung Kecamatan Parung Kabupaten Bogor. Jurnal Governansi, 1(1), 13-24.

[12] Daryanto, H. M. (2013). Administrasi Dan Manajemen Sekolah. Jakarta: Rineka Cipta.
[13] Danim, S. (2014). Motivasi Kepemimpinan dan Efektivitas Kelompok. Jakarta: PT Rineka Cipta.

[14] Da'i, W. (2009). Pengaruh Supervisi Kepala Sekolah dan Kompetensi Pedagogik Guru terhadap Kinerja guru SD Negeri Kec. Kersana Kab. Brebes (Doctoral dissertation, Universitas Negeri Semarang).

[15] Depdiknas. (2011). Supervisi Akademik, Jakarta: Ditjen PMPTK

[16] Depdikbud, (2011). Kamus Besar Bahasa Indonesia. Jakarta: Balai Pustaka.

[17] Engkoswara \& Komariah, A. (2011). Administrasi Pendidikan. Bandung: Alfabeta.

[18] Erwinsyah, A. (2017). Manajemen Pembelajaran dalam Kaitannya dengan Peningkatan Kualitas Guru. Tadbir: Jurnal Manajemen Pendidikan Islam, 5(1), 69-84.

[19] Faturrohman, M. \& Sulistyorini. (2012). Belajar dan pembelajaran meningkatkan mutu pembelajaran sesuai standart Nasional. Yogjakarta: teras.

[20] Fathurrahman, M. (2015). Model Model Pembelajaran Inovatif.Jakarta: Ar-Ruzz Media.

[21] Gomes, F. (2010). Manajemen Sumber Daya Manusia. Yogyakarta: Penerbit Andi.

[22] Hasibuan, S. P. (2015). Manajemen Sumber Daya Manusia. Jakarta: Penerbit: PT. Bumi Aksara, Jakarta. 